\title{
The Evolution of the Corporate Social Performance Model
}

\author{
STEVEN L. WARTICK \\ PHILIP L. COCHRAN \\ Pennsylvania State University
}

This paper traces the evolution of the corporate social performance model by focusing on three challenges to the concept of corporate social responsibility: economic responsibility, public responsibility, and social responsiveness. It also examines social issues management as a dimension of corporate social performance. It concludes that the corporate social performance model is valuable for business and society study and that it provides the beginnings of a paradigm for the field.

The term "corporate social performance" (CSP) has been used for several years in the business and society literature. In most cases, CSP has not been defined precisely; it has been used as a synonym for corporate social responsibility, corporate social responsiveness, or any other interaction between business and the social environment. More recently, however, CSP has started to take on a more precise meaning.

As first described by Carroll (1979), CSP is the three dimensional integration of corporate social responsibility, corporate social responsiveness, and social issues. This integrative nature of CSP is what makes it unique. Instead of arguing that economic responsibility and public policy responsibility are inconsistent with social responsibility (Buchholz, 1977; Friedman, 1962; Heyne, 1968; Preston \& Post, 1975), the CSP model integrates economic responsibility and public policy responsibility into its definition of social responsibility. Instead of viewing responsibility, responsiveness and issues as separate, alternative corporate concerns (Ackerman \& Bauer, 1976; Frederick, 1978; Murphy, 1978; Sethi, 1979), the CSP model reflects an underlying interaction among the principles of social responsibility, the process of social responsiveness, and the policies devel-

Reprints of this article may be obtained from Steven L. Wartick, 321 Carpenter Building, Pennsylvania State University, University Park, PA 16802. oped to address social issues. The CSP model relies on this expanded version of social responsibility and this principle/process/policy approach in order to provide a distinctive view of a corporation's overall efforts toward satisfying its obligations to society.

By integrating social responsibilities, social responsiveness, and social issues, the CSP model provides a valuable framework for overall analyses of business and society. CSP has a microlevel dimension: it focuses on the interface between the firm and its environment, rather than on the relationship between business as an institution and the society in which it operates (Jones, 1983; Preston \& Post, 1975). However, CSP does retain an emphasis on the macro-level by continuing to use social responsibility as the starting point for corporate social involvement. As such, the CSP model describes the totality of a firm's efforts to meet changing societal conditions, and thus it provides a starting point for the eventual development of a central paradigm for business and society (Preston, 1975).

Whether the CSP model ultimately leads to a central paradigm for business and society is an intriguing question, but a question still largely a matter for the future. Of equal importance for those who are interested in business and society is the historical evolution of the CSP model. In scholarly inquiry, new models do not appear suddenly. They evolve through a process of 
analysis, debate, and modification. The value of a model therefore is as much a function of its past as its future.

In his 1979 work Carroll covered much of the background literature of his CSP model. However, his review failed to capture the model's dynamic evolution. It failed to capture the process of analysis, debate, and modification that characterizes scholarly inquiry. In the present paper the evolution of the CSP model is traced. The thesis is that the CSP model has grown out of the major scholarly "confrontations" that occurred during the most recent 30-year debate about corporate social responsibility.

\section{Two Basic Premises}

Thirty years ago, H.R. Bowen argued that businessmen have an obligation "to pursue those policies, to make those decisions, or to follow those lines of action which are desirable in terms of the objectives and values of our society" (1953, p. 6). With this simple proposition Bowen touched off what can be called "the modern debate" about social responsibility. As Heald (1970), Eberstadt (1973), and others have shown, this most recent 30-year period is not the only time when social responsibility was a major societal concern. However, social responsibility was most thoroughly examined and vigorously analyzed in the past three decades.

The concept of social responsibility-as suggested by Bowen's emphasis on the objectives and values of society-rests on two fundamental premises. First, business exists at the pleasure of society; its behavior and methods of operation must fall within the guidelines set by society. Like government, business has a social contract-an implied set of rights and obligations. The specifics of the contract may change as societal conditions change, but the contract in general always remains as the source of business legitimacy (Donaldson, 1983). This social contract is the vehicle through which business behavior is brought into conformity with society's objectives.

The second premise underlying social responsibility is that business acts as a moral agent within society (Ozar, 1979; Rawls, 1971). Like states and churches, corporations reflect and reinforce values. As Donaldson argues, corporations have: (a) "the capacity to use moral rules in deci- sion making" and (b) "the capacity to control not only overt corporate acts, but also the structure of politics and rules" (1982, p. 30). Corporations therefore meet the conditions of moral agency and must behave in a manner consistent with society's values. An ethical dimension to business behavior and responsibility is the logical result.

These two ideas - the social contract and moral agency-have provided the basic premises of the social responsibility concept. Yet, they also have provided the two major targets for critics of social responsibility. The arguments of these critics are revealed in three major challenges to social responsibility.

\section{Challenges to Social Responsibility}

Since Bowen's seminal work, both scholars and practitioners have attempted to review and redefine the basic concept of social responsibility. From these efforts have come the three challenges to social responsibility. Each challenge was offered as something more than a mere complement to social responsibility; each was intended as an alternative to social responsibility in management thinking. Each challenge attempted to redefine both the scope of corporate responsiblities in society and the criteria for measuring managerial performance in the social arena.

\section{Challenge 1: Economic Responsibility}

Although economic responsibility is based on the assumptions of classical economic doctrine, in the context of this debate it was raised as a challenge to corporate social responsibility. Friedman $(1962,1970)$ is the most ardent proponent of economic responsibility, although others (Haas, 1979; Heyne, 1968) continue to try to clarify and extend the argument. The challenge of economic responsibility begins on the macro-level by attacking both the social contract premise and the moral agency premise of social responsibility; it continues by deriving micro-level implications.

The Criticism. According to Friedman (1962, 1970), the only social responsibility of business is to maximize profits within "the rules of the game." The sole constituency of business management is the stockholders, and the sole concern of the stockholders is financial return. If, 
through socially responsible acts (e.g., urban investments, philanthropy, or minority purchasing programs), managers reduce the return to stockholders, then they are, in effect, levying taxes on the corporation. By determining how these self-imposed taxes will be spent, managers undermine the market mechanism for allocating resources and they appoint themselves as nonelected public policymakers. In short, social responsibility is a "subversive" doctrine (not a complementary doctrine) in the social contract of business in a free society.

The challenge of economic responsibility argues that corporations cannot be moral agents. Only individuals can have moral responsibilities. If managers, owners, customers, or employees choose to use their personal property (i.e., salaries, dividends, income, or wages) in efforts to resolve society's problems, so be it. But, to the extent that managers use corporate resources to promote socially responsible activities, they are "stealing" from owners' dividends, from customers' wealth, or from employees' wages. Thus, even on ethical grounds, the concept of social responsibility as anything more than profit maximization is inappropriate.

In sum, the proponents of economic responsibility contend that improving profitability is the only socially responsible activity of business. The criteria for judging managerial performance is how well managers meet the objective of improving profitability.

The Response. The response to this first challenge has been to point out that the assumptions of economic responsibility are unrealistic. Some who reject economic responsibility focus on the managerial implications. For example, Walters (1977) argues that economic responsibility is not a useful guide for managers because: (a) it neglects the long run consequences of profit maximization and (b) it fails to identify the appropriate relationship between the manager and changing political and legal conditions. A manager who adheres to the economic responsibility concept runs the risk of becoming the target of government regulation but has no clear direction in relation to political involvement. If the manager chooses to stay out of the political process, shareholders' interests may suffer. If the manager chooses to become involved in the political process, then the firm takes on a political dimension and ceases to be strictly an economic institution. The firm's behavior is subjected to political evaluation, and its economic justifications for behavior are discounted.

Others who reject the realism of economic responsibility focus on scope and argue that the business community never has adhered strictly to a concept of economic responsibility (McKie, 1974). Philanthropy, community involvement, paternalism, and voluntary codes of ethics are all indicators of a longstanding, pragmatic divergence from the concept. They also argue that economic responsibility ignores the reality of "market failures"- especially in cases in which costs are not paid for and in which the seller has considerably more information than the buyer (Arrow, 1973). Again, the point is that economic responsibility is not realistic.

In general, those who argue that economic responsibility is not the only social responsibility of business are saying that economic responsibility fails to recognize that modern businesses, especially the megacorporations, are no longer mere economic institutions. Through such activities as lobbying, providing Congressional testimony, and establishing political action committees, corporations have added a political dimension. Because corporate behavior is so critical to the realization of social goals such as equal opportunity, worker safety and health, and environmental protection, a social dimension is added to corporate performance. Because corporations are the major societal entities that develop and apply new technologies, a dimension of their performance rests with technology assessment. To view the modern corporation in a strict economic sense is to ignore reality, and to suggest that its responsibilities include only economic obligations is myopic.

\section{Challenge 2: Public Responsibility}

Public responsibility is a relatively recent challenge. Its roots, however, seem to go back to Levitt who, in response to Bowen, argued:

Business should recognize what government functions are and let it go at that, stopping only to fight government where government directly intrudes itself into business. It should let government take care of the general welfare so that business can 
take care of the more material aspects of welfare (1958, p. 49).

Preston and Post (1975, 1981) and Buchholz $(1977,1982)$, extending this notion of separation of responsibilities, offer public responsibility as a substitute for social responsibility. These advocates of public responsibility focus more on the social contract of business and less on the question of moral agency. They maintain an emphasis on macro-level concerns, but they also try to move the discussion to more of a micro-level by addressing organizational responses.

The Criticism. Preston and Post $(1975,1981)$ begin by arguing that business and society are interpenetrating systems. The systems are linked through the market process and the public policy process. Public responsibility comes from the recognition of a corporation's primary and secondary involvements. Primary involvements are the essential economic tasks of the firm; secondary involvements are the consequential effects resulting from the performance of those primary functions. The market provides direction for the corporation in relation to primary involvements, and the public policy process provides direction for secondary involvements. The organization should "analyze and evaluate pressures and stimuli coming from public policy in the same way it analyzes and evaluates market experience and opportunity" (Buchholz, 1982, p. 435). Corporations therefore have a dual responsibility-a responsibility to the market (similar to economic responsibility as discussed above) and a responsibility to the public policy process. The criteria for measuring managerial performance rest with how well managers respond to both sets of responsibilities. Thus, public responsibility provides a construct for clarifying relevant and irrelevant corporate concerns, and it offers guidelines for implementing and evaluating managerial action. It is based on an orientation that integrates micro-level and macro-level considerations.

In the public responsibility concept, public policy extends beyond the traditional understanding that "public policy equals the law." In this concept public policy refers to "widely shared and generally acknowledged principles directing and controlling actions that have broad implications for society at large or major portions thereof" (Preston \& Post, 1975, p. 56). Public policy includes "the broad pattern of social direction reflected in public opinion, emerging issues, formal legal requirements, and enforcement or implementation practices" (Preston \& Post, 1981, p. 57). When public policy is considered in this broader context, public responsibility goes beyond the Friedmanian (1962) dictum of maximize profits within the rules of the game. Managers are encouraged to participate in the public policy development process.

The problem that advocates of public responsibility are attempting to address relates to perceived ambiguity of the social responsibility concept. Preston and Post argue that social responsibility is "vague and ill-defined," and that it:

provides no basis for dealing concretely with possible conflicts between traditional corporate goals and social objectives; and it suggests no boundary between the genuine responsibilities of business management and the entire range of activity within the host society $(1975$, p. 52$)$.

They therefore offer public responsibility as a replacement for social responsibility. Buchholz (1977) suggests that two major problems with social responsibility make this replacement necessary. They are: (a) allocating resources to be used in dealing with social issues and (b) developing accountability when business makes social decisions. Preston and Post, as well as Buchholz, have argued that the use of public responsibility eliminates these problems associated with social responsibility.

The Response. For those who argue against substituting the concept of public responsibility for social responsibility, the major concern is how public policy is defined. If, for example, public policy is defined as broadly as Preston and Post suggest (widely shared and generally acknowledged principles of society or public opinion, emerging issues, formal law, and enforcement practices), then nearly all environmental change is included as public policy. Because the public policy process is the major societal mechanism for articulating changing social conditions, the differences between public policy development and social change are difficult, at best, to distinguish. Also, the differences between public policy and Bowen's "societal values and objec- 
tives" are less clear. Effectively, public responsibility and social responsibility become synonymous.

If public policy is defined in the more traditional sense (as governmental legislative development), then public responsibility is too narrowly conceived. This is Jones' point when he argues that using the public responsibility concept is too restrictive because:

1. Public policy does not address many issues that confront corporations in social policy areas.

2. Conflicting statements or expressions of public policy exist at the same level in many areas of corporate social involvement.

3. Statements of public policy emerge from several levels of government, "whose public policy should be heeded?"

4. Public policy can conflict with "higher laws" or "higher moral codes" (1980, p. 64).

Perhaps Jones' points merely reflect the "realworld" difficulties that affect any normative approach to corporate social involvement (Preston \& Post, 1981). Yet, the fact remains that this narrower conceptualization of public policy is too restrictive for operationalizing the business and societal interaction.

In short, the critics argue that because of ambiguity in defining public policy, public responsibility adds little as an alternative to social responsibility. If public policy is defined in the broader sense, it is hard to distinguish from social responsibility. If public policy is defined in the narrower sense, it is too restrictive in terms of the scope of corporate responsibilities in society. The challenge of public responsibility does call for increased discussion of how corporate responsibilities may be realized, and in that sense it adds to the debate about corporate social involvement. However, public responsibility as a substitute for social responsibility is still lacking.

\section{Challenge 3: Social Responsiveness}

The third challenge to social responsibility comes in the form of social responsiveness. Social responsiveness is intended to shift the emphasis away from social obligations and to social response processes. As such, social responsiveness is targeted at both the social contract and the moral agency of business.

The Criticism. Like those critics before them, the advocates of social responsiveness find social responsibility to be operationally dysfunctional.
Ackerman and Bauer, for example, argue that social responsibility "gives little guidance as to the content of what is to be done beyond 'something more,' and it deflects our attention from much that is important"' (1976, p. 7). They base their judgment on three concepts that they believe underlie social responsibility-the conscience of the executive, costs of foregone profits, and voluntary discretion. All of these concepts are difficult, if not impossible, to assess, and each contributes to the ambiguity surrounding social responsibility.

Two other scholars place social responsiveness in a position beyond social responsibility in an evolutionary pattern of corporate social involvement. Sethi (1979) argues that a broadening conception of legitimacy has moved corporate social involvement from social obligation (a rough equivalent of economic responsibility), to social responsibility (with its prescriptive orientation), to social responsiveness. Murphy (1978) suggests that the current period of social responsiveness (1974 to the present) has been preceded by periods of issue emphasis (1968-1973); awareness development, that is social responsibility (19531967); and philanthropy (to the early 1950s). Both of these works imply that social responsiveness is an advanced way of thinking about corporate social involvement.

As the replacement for social responsibility, social responsiveness takes on more of a means orientation. Social responsiveness "refers to the capacity [italics added] of a corporation to respond to social pressures" (Frederick, 1978, p. 6 ). Whereas social responsibility is a noun, social responsiveness is a verb. Whereas social responsibility leans toward philosophical discourse, social responsiveness "shuns philosophy in favor of a managerial approach" (Frederick, 1978, p. 7). In all, the advocates of social responsiveness see it as a more tangible, achievable objective than social responsibility, and they see it as "a genuine replacement of the idea of 'responsibility' and ... not simply one of those fashionable changes in phraseology that occasionally takes the scholarly community by storm" (Frederick, 1978, p.6).

The Response. Concern with social responsiveness is not, as is the case with economic responsibility, a matter of the usefulness of the point of 
view. Social responsiveness is a valid concept that leads managers to a clearer emphasis on implementation and policy development. The concern here is similar to the question raised about public responsibility, that is, is social responsiveness a valid replacement for social responsibility? If social responsiveness replaces social responsibility in management thinking, what is lost and what is gained in terms of some of the most important questions of corporate social involvement?

First, it can be argued that to replace social responsibility with social responsiveness eliminates or at least dramatically deemphasizes considerations of business ethics and social irresponsibility. Social responsiveness tends to be guided by prevailing social norms; social responsibility attempts to determine fundamental ethical truths. There can be ethical problems and irresponsible actions without public outcry, awareness, and pressure. To attempt to determine what is fundamentally right or wrong is not a frivolous exercise. As most critics of social responsibility point out, ethical analysis does not always provide strong, empirically testable, pragmatic results. But that does not necessarily diminish the value of the concept. Consider such concepts as "self-actualization" in organizational behavior or "competition" in economics; these concepts suffer from similar empirical and pragmatic deficiencies, but still they have provided valuable insights into the workings of human and economic systems. Social responsibility adds a similar dimension to corporate performance, and whether social responsiveness by itself maintains an adequate level of ethical inquiry is doubtful.

Second, social responsiveness does not require continual evaluation of the relations between corporate objectives and societal objectives. Without some sense of social responsibilities to guide activities, the corporation is left with a potpourri of demands all of which are impossible to meet. As a result, social responsiveness by itself is likely to lead to reaction rather than the proaction that many advocates of responsiveness call for.

Third, social responsiveness seems to ignore what Davis (1973) called the Iron Law of Responsibility-if an institution has social power, that institution must use its power responsibly or the power will be taken away by society. Being responsive does not necessarily mean the same thing as being responsible. As Epstein (1979) has argued, social responsibility relates to outcomes or products, whereas social responsiveness relates to process; these two perspectives have significantly different implications for the firm. Suppose, for example, that a multiproduct firm's social responsibility is to produce reasonably safe products. Similarly, the same firm is responsive every time it produces an unsafe product: it withdraws the product from the market as soon as the product is found to be unsafe. After, say, 10 recalls, will the firm be recognized as socially responsible? Will the firm be recognized as socially responsive? The likely answers to these questions are "no" to the first, but "yes" to the second. Over the long term, the socially responsive firm's existence may be threatened by the Iron Law of Responsibility.

\section{CSP: A Synthesis of the Challenges}

As noted earlier, the distinctive features of the CSP model are its expanded conceptualization of social responsibility and its integration of responsibilities, responsiveness, and issues through a principle/process/policy approach. In a paper that followed the Carroll model of CSP by four years, Strand (1983) took these two basic features and developed a systems paradigm for organizational adjustment to the social environment. Like Carroll; Strand argues that the three dimensions of responsibility, responsiveness and responses are fundamentally linked to form a system of corporate social involvement. Social responsibilities are determined by society, and the tasks of the firm are: (a) to identify and analyze society's changing expectations relating to corporate responsibilities, (b) to determine an overall approach for being responsive to society's changing demands, and (c) to implement appropriate responses to relevant social issues. Whereas Carroll emphasizes the relationship between responsibility and responsiveness, Strand emphasizes the more micro-level concerns of responsiveness and responses. Strand does more than Carroll with the third dimension of CSP-developing responses to issues-by elaborating both internal and external responses to environmental change. However, the two basic features of 
CSP - an expanded conceptualization of social responsibility and an integration of responsibilities, responsiveness and responses - remain unchanged. Thus, Strand's model can be considered an extension of the principles/process/policies relationship underlying CSP thinking.

As illustrated in Table 1, the first two challenges to social responsibility-economic and public-have been assimilated into a more all encompassing definition of social responsibility found in the CSP model. In addition, the dual level orientation-macro-level along with microlevel concerns-of public responsibility has been adopted by CSP. The third challenge-social responsiveness-has been incorporated into the CSP model as the critical link between social responsibilities and responses to social issues.

\section{The CSP Perspective of Economic Responsibility}

The CSP model recognizes and accepts the importance of economic responsibility. However, instead of arguing that economic and social responsibility are mutually exclusive, economic responsibility is identified as a subset of social responsibility. As noted by McGuire, "The idea of social responsibilities supposes that the corporation has not only economic and legal obligations, but also certain responsibilities to society which extend beyond those obligations" (1963,

Table 1

The Corporate Social Performance Synthesis of the Three Major Challenges to Social Responsibility

\begin{tabular}{|c|c|}
\hline Challenge & CSP synthesis \\
\hline $\begin{array}{l}\text { 1: Economic } \\
\text { responsibility }\end{array}$ & $\begin{array}{l}\text { Incorporated as one level of } \\
\text { corporate social responsibility }\end{array}$ \\
\hline 2: Public responsibility & $\begin{array}{l}\text { Incorporated as (1) one level } \\
\text { of corporate social responsibility } \\
\text { and ( } 2 \text { ) the underlying orientation } \\
\text { for macro-level and micro-level } \\
\text { concerns existing simul- } \\
\text { taneously. }\end{array}$ \\
\hline 3: Social responsiveness & $\begin{array}{l}\text { Incorporated as (1) the action } \\
\text { oriented complement to corpor- } \\
\text { ate social responsibility and } \\
\text { (2) the underlying approach to } \\
\text { the development of responses } \\
\text { to social issues. }\end{array}$ \\
\hline
\end{tabular}

p. 144). The point is that social responsibility includes, but is not limited to, economic responsibility.

To illustrate this integrated view of economic and social responsibilities, consider Carroll's (1979) and Strand's (1983) models. Carroll's model defines social responsibility as consisting of economic, legal, ethical, and discretionary responsibilities. Strand's concept of social reponsibility describes four concerns: (a) the cultural and economic environments, (b) material, social, and psychological experience of constituents, (c) social demands and expectations placed on organizations, and (d) the environmental texture of organizations. Both authors incorporated economic responsibility into the principles underlying their models and thus incorporated economic responsibility into the definition of social responsibility.

Other recent research supports the idea that economic and social responsibilities are not mutually exclusive but are parts of some more all encompassing concept of corporate responsibilities. Zenisek (1979), for example, argued that corporate social responsibility is really nothing more than a fourth layer of managerial responsibility resulting from the evolution of American capitalism. Economic responsibility and social responsibility (the first and fourth layers) are not trade-offs but rather components of overall societal responsibilities of business. Tuzzolino and Armandi (1981) have offered a need-hierarchy framework for corporations that is similar to Maslow's need hierarchy for individuals. In their framework, the lowest level of responsibility (the physiological needs equivalent) is profitability, and the highest level of responsibility (the selfactualization needs equivalent) is social responsibility. As in Maslow's model, prepotency exists such that the need for profitability (economic responsibility) predominates if it is not being satisfied. But, in self-actualizing, the firm appeases all of its claimants (it is socially responsible). Recently, Drucker (1984) reemphasized this position by arguing that capital formation and, thus, profitability is the most fundamental responsibility of the firm. Other responsibilities follow profitability and should not be excluded from management's consideration solely because they decrease profit. 


\section{The CSP Perspective of Public Responsibility}

The CSP model deals with the second challenge, as it does with economic responsibility, by incorporating public responsibility into the definition of social responsibility. Like economic responsibility, the challenge of public responsibility expands but does not replace social responsibility. In Carroll's model, the legal component of social responsibility covers the narrower definition of public responsibility, and the discretionary component covers the broader definition. In Strand's model public responsibility is implicit in his category of "social demands and expectations placed on organizations." Strand equates these demands and expectations to "legal, economic and social pressures" (1983, p.92).

Most notable of other recent research supporting the inclusion of public responsibility within social responsibility is Dalton and Cosier's (1982) four faces of social responsibility. In fact, this conceptualization of social responsibility addresses the major criticism of public responsibility by integrating the narrow definition of public policy with the broad definition of public policy. Dalton and Cosier's framework is based on four types of corporate activities: (a) illegal and irresponsible acts, (b) illegal but responsible acts, (c) legal but irresponsible acts, and (d) legal and responsible acts. The narrow notion of the public responsibility concept exists in the legal/illegal dimension of the framework. The broader definition exists in the linkage between the legal/illegal dimension and the responsible/irresponsible dimension.

In addition to incorporating public responsibility into the definition of social responsibility, the CSP model accepts the general orientation of public responsibility, that is, that macro-level and micro-level concerns exist simultaneously in corporate social involvement. Public responsibility rests on the macro-level notion of interpenetrating systems and on the micro-level notion of primary and secondary involvements; CSP maintains this dual level orientation through its integration of social responsibility and social responsiveness.

\section{The CSP Perspective of Social Responsiveness}

The CSP model argues that social responsibility and social responsiveness are equally valid concepts and that both should be included as separate dimensions of corporate social involvement. For example, in Carroll's model, social responsiveness is comprised of reactive, defensive, accommodative, and proactive approaches. As summarized by Carroll:

Corporate social responsiveness, which has been discussed by some as an alternate to social responsibility is, rather, the action phase of management responding in the social sphere. In a sense, being responsive enables organizations to act on their social responsibilities without getting bogged down in the quagmire of definitional problems that can so easily occur if organizations try to get a precise fix on what their true responsibilities are before acting (1979, p. 502).

In Strand's model, social responsiveness is comprised of (a) organizational type and characteristics, (b) monitoring and boundary spanning, (c) management social values and goals, (d) social response mechanisms, and (e) decision processes (1983, p. 92). Carroll's model therefore emphasizes the link between social responsibility and social responsiveness, and Strand's model emphasizes the link between social responsiveness and social policy.

Both Carroll and Strand view responsibility and responsiveness as vital, complementary concepts; they argue that the two concepts merely play different roles in the understanding of CSP. Social responsibility maintains a macro emphasis and social responsiveness provides a micro emphasis. Although neither Carroll nor Strand attempts to differentiate precisely the distinct roles of social responsibility and social responsiveness, such a task is important to the CSP model. Thus, in Table 2 , a summary of the differences between social responsibility and social responsiveness is presented.

\section{Social Issues Management: The Third Dimension of CSP?}

Although the first two dimensions of CSPsocial responsibility (including economic and public responsibilities) and social responsiveness-clearly grow out of the debate involving the three challenges to social responsibility, the third dimension of CSP is still in its formative stage. In Carroll's model, the third dimension consists only of issue areas. In Strand's model, the third dimension is more fully developed around 
Table 2

Differences Between Social Responsibility and Social Responsiveness

\begin{tabular}{lll}
\hline & \multicolumn{1}{c}{$\begin{array}{c}\text { Social } \\
\text { responsibility }\end{array}$} & \multicolumn{1}{c}{$\begin{array}{c}\text { Social } \\
\text { responsiveness }\end{array}$} \\
\hline Major considerations & Ethical & Pragmatic \\
Unit of analysis & Society & The firm \\
Focus & Ends & Means \\
Purpose & "Window out" & "Window in" \\
Emphasis & Obligations & $\begin{array}{l}\text { Responses } \\
\text { Role of the firm }\end{array}$ \\
& Moral agent & $\begin{array}{c}\text { Producer of goods } \\
\text { and services }\end{array}$ \\
Decision framework & Long term & $\begin{array}{c}\text { Medium and } \\
\text { short term }\end{array}$ \\
\hline
\end{tabular}

organizational responses to quality of life issues. CSP is moving toward social issues management as its third dimension.

\section{Background of (Social) Issues Management}

Issues management has been developing along parallel lines in three different areas-public issues management, strategic issues management, and social issues management. The only difference among these three areas is the type of issue considered-public issues relate to legislative matters, strategic issues have consequences requiring strategic change, and social issues relate to societal change in values and attitudes. The purpose and process of issues management in each area is substantially the same.

The purposes of issues management are to minimize "surprises" emanating from the turbulent business environment and to prompt systematic and interactive responses to environmental change (Brown, 1979; Gottschalk, 1982; "Issues Management," 1981). The process of issues management varies somewhat from organization to organization, but in general it consists of three stages: (a) issues identification, (b) issues analysis, and (c) response development (Johnson, 1983). The formalization of the issues management process was an attempt to address the myriad of issues that emerged in the late 1960s and early 1970s. Issues management was intended to fill the void between the short term, reactive perspective of public relations and the long term, futuristic perspective of corporate planning. In reality, issues management is a misnomer: responses, not issues, are managed.

In the public affairs area, issues management grew out of the work of Chase (1977). Primarily, Chase proposed a five stage process that leads to a more systematic approach to issues identification and response development. In strategic management, Ansoff $(1975,1980)$ and King (1982) have been most involved in the development of issues management. Beginning with Ansoff's idea that responses to "weak signals" are needed, the continuing emphasis has been on identifying and responding to issues of strategic importance. In the social issues area, Jacoby (1971), Ackerman (1973), Sethi (1975), Post (1978), and Fleming (1981) have led the way in issues management theory. Using expectational gaps as their basic conceptual tool, this group has focused on: (a) how social issues are defined and differentiated from social trends, (b) what common patterns exist in the development of social issues, and (c) what responses appropriately address the identified issues.

\section{Current Status of (Social) Issues Management}

Issues management-whether public, strategic, or social-is still suffering from problems associated with a new area. In practice, issues management continues to have problems with issues overload, quantification of analyses, policy/ program evaluation, and organizational credibility (Johnson, 1983). Even so, issues management has become an established component of public affairs management in several major corporations (Gollner, 1983; Post, Murray, Dickie, \& Mahon, 1983).

In theory, the current status of issues management is more promising. The life cycle of social issues is firmly established as a valuable analytical tool (Arcelus \& Schaefer, 1982; Post, 1978; Starling, 1984); and issues analysis, the critical linkage between issues identification and effective response development, is being significantly enhanced by "stakeholder analysis" (Freeman, 1984 ) and social cognition theory (Dutton, Fahey, \& Narayanan, 1983; Kiesler \& Sproul, 1982). 


\section{Social Issues Management and CSP}

To the extent that social issues management matures, it will provide the essential third dimension to CSP. Social issues management is a direct extension of social responsiveness. Out of necessity, it follows from the firm's understanding of social responsibility. It provides method to an area that has been continually criticized as "soft" and tangential to the true purpose of the corporation. In short, social issues management provides the final necessary ingredient to CSP.

\section{Concluding Commment}

During the past thirty years, the CSP model has grown out of an initial admonishment that firms need to be more socially responsible and into an integrative, three dimensional model of corporate social involvement. Social responsibility - thefirst dimension - has been an extremely resilient concept. It has assimilated much of the criticism that has been levied against it. Yet, the two fundamental premises of social responsibility-the social contract and moral agencyremain as the ethical component of social responsibility. Social responsiveness - the second dimension-provides the approach to realizing social responsibility. It has become the general means to the ends of satisfying corporate social obligations. Social issues management-the third dimension-is now being developed as the method for operationalizing social responsiveness. Figure 1 extends from Carroll (1979) to provide a summary of the CSP model. As shown in Figure 1 , the CSP model suggests that corporate social involvement rests on the principles of social responsibility, the process of social responsiveness and the policies of issues management. Each of the components has its distinctive direction and orientation; yet, in total, they provide an integrated conceptualization of corporate social involvement as it currently exists.

Clearly, CSP is the result of the analysis, debate, and modification that characterizes scholarly inquiry. Whether CSP becomes the central paradigm for business and society is still an open question, but two points illustrate its potential. First, CSP comes close to meeting what Jones has identified as the three descriptive characteristics of a paradigm: "(1) a unifying or integrating theme, (2) substantial orthodoxy in the basic parameters of research-theory, methods, and values, and (3) predictive or explanatory capability" (1983, p. 559). The unifying theme centers around the principle/process/policy approach; the substantial orthodoxy is consistent with what already exists in the theoretical and empirical work of the business and society field; and the predictive or explanatory capability at this point rests mainly with explanation rather than prediction. Second, the CSP model does pull together the three dominant orientations of those

Principles
Corporate Social
Responsibilities
(1) Economic
(2) Legal
(3) Ethical
(4) Discretionary
Directed at:
(1) The Social Con-
tract of Business
(2) Business as a Moral
Agent
Philosophical
Orientation

Figure 1. The corporate social performance model.

Institutional
Policies

Corporate Social Responsiveness

(1) Reactive

(2) Defensive

(3) Accommodative

(4) Proactive

Directed at:

(1) The Capacity to Respond to Changing Societal Conditions

(2) Managerial Approaches to Developing Responses Orientation
Social Issues Management

(1) Issues Identification

(2) Issues Analysis

(3) Response Development

Directed at:

(1) Minimizing "Surprises"

(2) Determining Effective Corporate Social Policies

Organizational Orientation 
in the field of business and society (Preston, 1975): the philosophical orientation relates primarily to the principles of social responsibility, the institutional orientation relates primarily to the process of social responsiveness, and the organizational orientation relates primarily to the policies of social issues management. In sum, the past, healthy discourse that led the development of the CSP model makes its future very promising.

\section{References}

Ackerman, R. W. (1973) How companies respond to social demands. Harvard Business Review, 51(4), 88-98.

Ackerman, R. W., \& Bauer, R. A. (1976) Corporate social responsiveness. Reston, VA: Reston.

Ansoff, I. (1975) Managing strategic surprise by response to weak signals. California Management Review, 18(2), 21-33.

Ansoff, I. (1980) Strategic issue management. Strategic Management Journal, 1, 131-148.

Arcelus, F., \& Schaefer, N. (1982) Social demands as strategic issues. Strategic Management Journal, 3, 347-357.

Arrow, K. (1973) Social responsibility and economic efficiency. Public Policy, 21, 303-317.

Bowen, H. R. (1953) Social responsibilities of the businessman. New York: Harper \& Row.

Brown, J. K. (1979) This business of issues: Coping with the company's environment. New York: The Conference Board No. 758.

Buchholz, R. A. (1977) An alternative to social responsibility. MSU Business Topics, 25(3), 12-16.

Buchholz, R. A. (1982) Business environment and public policy. Englewood Cliffs, NJ: Prentice-Hall.

Carroll, A. B. (1979) A three-dimensional conceptual model of corporate social performance. Academy of Management Review, 4. 497-506.

Chase, H. W. (1977) Public issue management: The new science. Public Relations Journal, 33(5), 25-26.

Dalton, D. R., \& Cosier, R. A. (1982) The four faces of social responsibility. Business Horizons, 25(3), 19-27.

Davis, K. (1973) The case for and against business assumption of social responsibilities. Academy of Management Journal, 16, 312-322.

Donaldson, T. (1982) Corporations and morality. Englewood Cliffs, NJ: Prentice-Hall.

Donaldson, T. (1983) Constructing a social contract for business. In T. Donaldson \& P. Werhane, (Eds.), Ethical issues in business (2nd ed., pp. 153-165). Englewood Cliffs, NJ: Prentice-Hall.

Drucker, P. (1984) The new meaning of corporate social responsibility. California Management Review, 26(2), 53-63.

Dutton, J. E., Fahey, L., \& Narayanan, V. K. (1983) Toward understanding strategic issue diagnosis. Strategic Management Journal, 4, 307-324.
Eberstadt, N. (1973) What history tells us about corporate responsibilities. Business and Society Review, 7, 76-81.

Epstein, C. M. (1979) Societal, managerial, and legal perspectives on corporate social responsibility. The Hastings Law Journal, 30, 1287-1320.

Fleming, J. E. (1981) Public issues scanning. In L. Preston (Ed.), Research in corporate social performance and policy (Vol. 3, pp. 154-174). Greenwich, CT: JAI Press.

Frederick, W. C. (1978) From CSR1 to CSR2: The maturing of business and society thought. Working Paper No. 279, Graduate School of Business, University of Pittsburgh.

Freeman, R. E. (1984) Strategic management: A stakeholder approach. Boston: Pitman.

Friedman, M. (1962) Capitalism and freedom. Chicago: University of Chicago Press.

Friedman, M. (1970, September 13) The social responsibility of business is to increase its profits. New York Times Magazine, pp. $33+$

Gollner, A. B. (1983) Social change and corporate strategy. Stamford, CT: Issue Action Publications.

Gottschalk, E. C., Jr. (1982, June 10) Firms hiring new type of manager to study issues, emerging trends. Wall Street Journal, p. 27.

Haas, P. F. (1979) The conflict between private and social responsibility. Akron Business and Economic Review. 10(2), 33-36.

Heald, M. (1970) The social responsibilities of business: Company, community, 1900-1960. Cleveland, OH: Case Western Reserve University Press.

Heyne, P. T. (1968) Private keepers of the public interest. New York: McGraw-Hill.

Issues management: Preparing for social change. (1981, October 28) Chemical Week, pp. 46-51.

Jacoby, N. (1971, July-August) What is a social problem? Center Magazine, pp. 35-40.

Johnson, J. (1983) Issues management-What are the issues? Business Quarterly, 48(3), 22-31.

Jones, T. M. (1980) Corporate social responsibility revisited, redefined. California Management Review, 22(3), 59-67.

Jones, T. M. (1983) An integrating framework for research in business and society: A step toward the elusive paradigm? Academy of Management Review, 8, 559-564. 
Kiesler, S., \& Sproul, L. (1982) Managerial response to changing environments: Perspectives on problem sensing from social cognition. Administrative Science Quarterly, 27, 548-570.

King, W. (1982) Using strategic issue analysis. Long Range Planning, 15(4), 45-49.

Levitt, T. (1958) The dangers of social responsibility. Harvard Business Review, 36(5), 41-50.

McGuire, J. W. (1963) Business and society. New York: McGraw-Hill.

McKie, J. W. (1974) Social responsibility and the business predicament. Washington, DC: Brookings Institution.

Murphy, P. E. (1978) An evolution: Corporate social responsiveness. University of Michigan Business Review, 6(30), 19-25.

Ozar, D. (1979) The moral responsibility of corporations. In T. Donaldson \& P. Werhane (Eds.), Ethical issues in business (1st ed., pp. 294-300). Englewood Cliffs, NJ: PrenticeHall.

Post, J. E. (1978) Corporate behavior and social change. Reston, VA: Reston.

Post, J. E., Murray, E. A., Jr., Dickie, R. B., \& Mahon, J. F. (1983) The public affairs function. California Management Review, 26(1), 135-150.

Preston, L. E. (1975) Corporation and society: The search for a paradigm. Journal of Economic Literature, 13, 434-453.
Preston, L. E., \& Post, J. E. (1975) Private management and public policy. Englewood Cliffs, NJ: Prentice-Hall.

Preston, L. E., \& Post, J. E. (1981) Private management and public policy. California Management Review, 23(3), 56-62.

Rawls, J. (1971) A theory of justice. Cambridge, MA: Harvard University Press.

Sethi, S. P. (1975) Dimensions of corporate social responsibility. California Management Review, 17(3), 58-64.

Sethi, S. P. (1979) A conceptual framework for environmental analysis of social issues and evaluation of business response patterns. Academy of Management Review, 63-74.

Starling, G. (1984) The changing environment of business. Boston: Kent.

Strand, R. (1983) A systems paradigm of organizational adjustment to the social environment. Academy of Management Review, 8, 90-96.

Tuzzolino, F., \& Armandi, B. R. (1981) A need-hierarchy framework for assessing corporate social responsibility. Academy of Management Review, 6, 21-28.

Walters, K. D. (1977) Corporate social responsibility and political ideology. California Management Review, 19(3), 40-51.

Zenisek, T. J. (1979) Corporate social responsibility: A conceptualization based on organizational literature. Academy of Management Review, 4, 359-368.

Steven L. Wartick is Assistant Professor of Business Administration and Coordinator of the Issues Management Research Program, Pennsylvania State University.

Philip L. Cochran is Assistant Professor of Business Administration, Pennsylvania State University. 